\title{
“Making-of” de si mesmo: documentário como tema e princípio formal de As Mulheres do Meu Pai, de José Eduardo Agualusa
}

\author{
Daniel Moutinho Souza \\ Universidade Federal do Rio de Janeiro \\ Colégio Pedro II - Rio de Janeiro
}

Resumo: 0 objetivo deste artigo é analisar a presença e importância de conceitos e conteúdos ligados ao cinema para a construção do romance As Mulheres do Meu Pai, do autor angolano José Eduardo Agualusa. 0 próprio texto do romance informa que o projeto inicial do escritor era o roteiro para um filme. Além disso, a protagonista é uma documentarista que, ao longo do enredo, produz um filme sobre seu suposto pai biológico. Por fim, a obra possui uma estrutura reflexiva que remete ao tipo de documentário conhecido como makingof, pois comenta e justifica elementos da sua própria constituição como obra literária.

Palavras-chave: Romance angolano, cinema documentário, making-of, ficção contemporânea

\begin{abstract}
The aim of this article is to analyze the presence and the importance of concepts and contents related to cinema in the built of the novel As Mulheres do Meu Pai, by Angolan author José Eduardo Agualusa. The text of the novel itself informs that the writer's initial project was the script to a movie. Besides, its main character is a documentary filmmaker who, throughout the plot, produces a movie about his claimed biological father. Finally, the novel has a reflexive structure that reminds the type of documentary known as a making-of, for it comments and justifies elements of its own constitution as a literary work.
\end{abstract}

Keywords: Angolan novel, documentary cinema, making-of, contemporary fiction 
"Mas eu precisava de fazer filho. Precisava de ver a minha segunda imagem. E fiz uma filha. (...) Nós os africanos, a nossa riqueza é filho."

Antonieta Júlio, Dancing in the edge 1

Um romance nasceu de um projeto de filme. É o que se afirma em seu próprio texto.

Se As Mulheres do Meu Pai, romance de José Eduardo Agualusa (2012), fosse de fato um filme, usaria o recurso conhecido como montagem alternada. ${ }^{2}$ De acordo com o Dicionário Teórico e Crítico de Cinema, a alternância "começa quando se apresenta, com uma certa regularidade, a repetição de um plano ou de um grupo de planos, conforme a estrutura de base ABABAB etc." (Aumont/Marie 2003: 13).

Esta obra de Agualusa é dividida em quatro partes, nomeadas pelo autor como "andamentos", num total de 95 capítulos.

Setenta destes contam a história de Laurentina, uma documentarista portuguesa. 0 enredo começa em Lisboa, no dia em que sua mãe, Doroteia, morre, e seu pai, Dário Reis, lhe entrega uma carta. Nela, Laurentina descobre que é filha adotiva; que, enquanto o casal morava na Ilha de Moçambique, Doroteia perdera uma criança durante o parto na mesma sala e hora em que outra mãe não teria resistido ao dar à luz. Assim, haviam sido trocadas as crianças.

O pai biológico de Laurentina seria um famoso músico angolano chamado Faustino Manso. Ela então decide ir para Angola, juntamente com o namorado, Mandume. Este propõe que, uma vez na África, eles façam um documentário sobre o encontro com essa família, e ela aceita. Mas assim que chegam a Luanda, leem num jornal local a notícia do falecimento de Faustino. Eles vão ao funeral, onde um dos netos do músico, Bartolomeu Falcato, propõe a Laurentina que façam juntos um documentário sobre a trajetória de Faustino Manso, indo às cidades onde ele viveu entre Angola, África do Sul e Moçambique. Tivera, nesse percurso, sete mulheres e dezoito filhos. 
Um termo recorrente no cinema é o road movie, "filme de estrada". Pois a partir daqui As Mulheres do Meu Pai se torna um "road novel": Bartolomeu, Laurentina e Mandume alugam um carro com motorista (um candongueiro, no linguajar local), atravessam a Namíbia e a África do Sul, e depois seguem rumo a Moçambique: é o "Roteiro de Faustino Manso". Conhecem quase todas as mulheres e alguns dos filhos dele, e registram os encontros em entrevistas e depoimentos para o filme. Ao final, Laurentina e Mandume retornam a Luanda e posteriormente a Lisboa, tendo suas vidas pessoais e seu relacionamento transformados pela experiência na África.

A estrutura de As Mulheres do Meu Pai é essencialmente polifônica. Esses setenta capítulos apresentam narradores alternados: Laurentina, Mandume, Bartolomeu e o motorista Albino Amador (de alcunha "Pouca Sorte") são os principais. Alguns poucos capítulos dão voz a outros personagens, e nestes ocorre uma variação de gêneros textuais, como a carta ("Carta de Doroteia para Laurentina" e "Carta de Alima à sua filha Laurentina") e o depoimento ("Faustino Manso, segundo Serafim Kussel” e "Fala de Alfonsina, a que ama o mar"). Desta forma, multiplicam-se os pontos de vista sobre o personagem biografado Faustino Manso e sobre o enredo em si.

Os outros 25 capítulos - entre os quais o primeiro de cada andamento e o último do romance - têm títulos que soam como páginas de um diário: local e data. Por exemplo, "Rio de Janeiro, Brasil. 24 de junho de 2005." Nestes, que chamaremos “capítulos-diário", também há variações de gêneros textuais (como trechos de entrevista e cartas).

Nos capítulos-diário, não são personagens Laurentina, Mandume etc. 0 narrador desse diário se confunde com o próprio autor José Eduardo Agualusa, e quase todos estes capítulos se passam na África, numa viagem entre Angola e Moçambique, que teria sido feita pelo escritor acompanhado da documentarista inglesa Karen Boswall e do fotógrafo catalão, radicado em Portugal, Jordi Burch, além do motorista contratado por eles, entre 2005 e 2006.

Essa viagem funciona como pesquisa e matéria-prima para o enredo do romance. Diversos elementos narrativos aparecem no diário (por exemplo, a companhia de uma documentarista e de um fotógrafo) e em seguida retornam, refigurados, na vida dos 
personagens, ou vice-versa. A montagem "alternada” faz com que tal diário seja ao mesmo tempo um comentário e um "making-of" do enredo, de maneira que o documentário seja ao mesmo tempo tema do romance (o filme produzido por Laurentina e Bartolomeu) e parte de seu princípio formal, pois o leitor tem acesso ao que seria a gênese de personagens, eventos ou cenários com que os protagonistas se defrontam. Dessa maneira, os capítulosdiário e o enredo refletem-se mutuamente.

\section{Documentário como princípio formal: making-of}

O making-of é um documentário: uma peça fílmica que registra os bastidores da produção de uma obra cultural, em geral um filme. Partimos da hipótese de que os capítulos-diário sejam um making-of do enredo do romance As Mulheres do Meu Pai, ao mesmo tempo que faz parte de seu conteúdo.

Dado o caráter polifônico da obra, por meio da alternância de narrador a cada mudança de capítulo, o leitor de início não percebe o espelhamento operado pelos capítulos-diário, uma vez que o autor desse diário parece ser apenas mais um entre os personagens e entre os narradores. Tal como os demais, ele se revela aos poucos. Todavia, tal espelhamento está presente desde o princípio. No primeiro capítulo, “Oncócua, sul de Angola. Domingo, 6 de novembro de 2005", diz o narrador:

Acordei suspenso numa luz oblíqua. Sonhava com Laurentina. Ela conversava com o pai, o qual, vá-se lá saber por quê, tinha a cara do Nelson Mandela. Era o Nelson Mandela, e era o pai dela, e no meu sonho tudo isso parecia absolutamente natural. (...) Sonhei também com uma frase. Acontece-me frequentemente. Eis a frase:

- De quantas verdades se faz uma mentira?

(...) Virei a cabeça e dei com o rosto de Karen. Dormia. A dormir Karen volta a ser jovem, como suponho que era antes da doença (da maldição). (Agualusa 2012: 15)

O último capítulo do Primeiro andamento intitula-se "Outro início". Ali, a expedição de Laurentina chega ao sul de Angola, e ela narra: "Acordei suspensa numa luz oblíqua. Virei a cabeça e dei com o rosto de Mandume. Dormia. A dormir Mandume volta a ser um menino. 
Quando o vejo assim sinto vontade de o abraçar." (idem: 107).

As semelhanças não se limitam a esta. A seguir, a primeira citação é do capítulodiário inicial, e a segunda, narrada por Laurentina:

Levantei-me com cuidado e espreitei pela janela. Uma enorme montanha, com o formato de um cone perfeito, flutuava no horizonte. Duas mulheres mucubais avançavam sem ruído. A mulher mais alta não devia ter mais de 16 anos, cintura estreita, pulseiras coloridas nos finos pulsos dourados; lembrei-me, ao vê-la, de um verso de Ruy Duarte de Carvalho - os seios: frágeis acúleos na placa do peito. (idem: 15, itálico no original)

Levantei-me com cuidado e espreitei pela janela. Duas mulheres mucubais (seriam mucubais?) avançavam sem ruído ao longo de uma larguíssima rua de terra batida. A mulher mais alta não devia ter mais de 15 anos, cintura estreita, a cintura que eu gostaria de voltar a ter, pulseiras coloridas nos finos pulsos dourados. Uma enorme montanha, com o formato de um cone perfeito, erguia-se no horizonte. Lembrei-me, ao vê-la, de uns versos de Eugénio de Andrade: "Também elas cantam, as montanhas / somente nenhum de nós / as ouve, distraídos / com o monótono sibilar do vento." (idem: 107)

Os paralelos são evidentes. A repetição de frases e cenas transmite a sensação de que estamos no mesmo cenário, praticando as mesmas ações. Apenas são outros os personagens e, portanto, os pontos de vista. Os primeiros existem no mundo histórico; os segundos, não. Não há hierarquia nem barreiras entre eles; em outras palavras, nesta obra, realidade e ficção se movem no mesmo espaço.

Mas as diferenças são igualmente reveladoras. A ficção não é uma cópia da realidade (assim como um relato com intenções verídicas tampouco o é), e sim uma refiguração dela, de acordo com os propósitos e as escolhas realizadas por seu autor. No diário, de narrador masculino angolano, é evocado um poema sobre os seios das mulheres mucubais; no outro, de narradora feminina portuguesa, são lembrados versos sobre a paisagem. Além disso, Laurentina não tem certeza da etnia daquelas mulheres, os seios dela não lhe chamam atenção, e ela faz uma observação pessoal sobre suas cinturas, ausente do primeiro caso.

Deste modo, os capítulos-diário compõem um making-of do romance porque dão ao leitor conhecer as condições e os critérios que motivaram a invenção da história e dos 
personagens.

Retornando ao início do romance, quando Karen acorda, ela e o narrador-autor travam o seguinte diálogo:

- Sonhei com a Laurentina...

- A sério? Isso é bom. As personagens começam a existir no momento em que nos aparecem em sonhos.

- No meu sonho ela era indiana. Uma rapariga de cabelo liso, olhos grandes, pele muito escura.

- Não pode ser. Talvez meio indiana, não te esqueças que o pai é português...

- 0 pai?! Qual deles?...

- Boa pergunta. O Faustino Manso era luandense, mulato ou negro. 0 que a adotou era português, e o biológico...

- Não pensámos nisso...

- Tens razão, não pensámos nisso. Quem diabo era o verdadeiro pai de Laurentina? (Idem: 16)

Nesta conclusão do capítulo inicial estão os principais temas do romance: a busca, por Laurentina, de seu pai biológico; a incerteza sobre a identidade dele; a relação entre o sonho - e o imaginário, a ficção, ou a mentira - e a realidade. E, não menos importante, nesse diálogo Karen aparece como interlocutora e cúmplice na criação e no desenvolvimento da protagonista. A pergunta final deixa claro que o autor ainda não tem em mente o desfecho da narrativa.

O capítulo seguinte é narrado por Laurentina, no momento da morte de sua mãe, quando soube ser adotada:

O meu pai, ou melhor, o homem que até àquela tarde eu acreditava que fosse o meu pai. (...) Deve ter ensaiado a pergunta noites a fio na solidão de seu quarto de viúvo:

- De quantas verdades se faz uma mentira? (idem: 17)

Nesse momento há a primeira interseção entre o capítulo-diário e o enredo propriamente dito: o autor atribui ao personagem Dário a pergunta com que sonhara em Oncócua. Dário prossegue: “Muitas, Laurentina, muitas! Uma mentira, para que funcione, 
há-de ser composta por muitas verdades. [...] Era uma boa mentira, a nossa, uma mentira composta por muitas verdades, e todas elas felizes" (ibidem).

Curiosamente, o enredo do romance revelará precisamente o oposto: um conjunto de mentiras que forma uma verdade, ou pelo menos é tacitamente aceito como tal.

O capítulo-diário seguinte é um flashback que narra como Agualusa conheceu Karen Boswall: primeiro na capital moçambicana, Maputo; depois, apresentando um documentário, Marrabentando, em um festival de cinema na Bahia. 0 narrador afirma que "ela quer muito que eu a ajude a escrever um roteiro para um filme musical, ou com um forte componente musical, sobre a situação das mulheres no cone sul de África." (Idem: 25). Essa entrada do diário data de junho de 2005, meses antes de partirem juntos em viagem, e a essa altura o enredo parece já bastante desenvolvido:

Esboçámos um roteiro. Queremos contar a história de uma documentarista portuguesa que viaja até Luanda para assistir ao funeral do pai, Faustino Manso, famoso cantor e compositor angolano. A partir de certa altura Laurentina decide reconstruir o percurso do pai, o qual, durante os anos 60 e 70 , percorreu toda a costa da África Austral, desde Luanda à Ilha de Moçambique. Faustino ficava dois ou três anos em cada cidade, às vezes um pouco mais, fundava uma família, e voltava à estrada. Em cada cidade visitada Laurentina grava os testemunhos das viúvas de Faustino, e dos seus numerosos filhos, bem como de muitas outras pessoas que conviveram com ele. 0 retrato que pouco a pouco começa a emergir é o de um homem misteriosamente complexo. No final Laurentina descobre que Faustino era estéril. (idem: 25-26)

É desnecessário enfatizar a referência ao universo cinematográfico: "roteiro". Aqui, Agualusa apresenta todo o enredo, que não se tornou filme, mas o próprio romance a que esse trecho pertence. Há uma pequena diferença entre esse plano e o resultado final Laurentina só recebe a notícia da morte de Manso ao chegar a Luanda - e, curiosamente, o autor antecipa o desfecho, ao revelar a esterilidade do cantor.

A partir desse comentário metanarrativo, o leitor pode perceber que esse diário não pertence ao mesmo campo diegético dos demais capítulos, uma vez que o narrador e Karen planejam a trajetória dos demais personagens. 
Uma pesquisa simples na internet revela que as pessoas e lugares citados nas páginas do diário pertencem ao mundo histórico, à chamada "vida real": a documentarista inglesa Karen Boswall, o fotógrafo catalão Jordi Burch, e posteriormente o artista angolano Kiluange Liberdade, o fotógrafo Ricardo Rangel, entre outros. ${ }^{3}$ A mistura entre o plano real e o fictício é, desta forma, componente estrutural de As Mulheres do Meu Pai. Cabe descrever como esse movimento reverbera em seu conteúdo.

Ao longo da narrativa, não são apenas os percursos de viagem do autor e dos personagens que coincidem. É frequente que elementos surjam nos capítulos-diário e reapareçam no caminho de Laurentina, Mandume e Bartolomeu, sempre de maneira refigurada, como a sinalizar que disso se trata a ficção: uma invenção, criação, a partir de elementos da experiência de quem a produz. Uma poiesis originada de uma mimesis.

Já observamos como isso se dá nos primeiros capítulos, quando o narrador do diário sonha com Laurentina e uma frase. Tomemos dois outros exemplos:

1) Nos capítulos-diário de 30 e 31 de outubro de 2005, José Eduardo Agualusa, Karen Boswall e Jordi Burch saem de Luanda: "em vez de um jipe estamos a fazer uma viagem numa carrinha, do tipo daquelas que em Angola, e um pouco em toda a África, cumprem o papel de táxis coletivos. Enfim: um candongueiro." (Idem: 58). O diário refere-se ao motorista como "Azarado". Compare-se: o candongueiro contratado por Laurentina para a viagem é apelidado "Pouca Sorte".

Azarado diz que possui 18 filhos, e quando perguntado "De quantas mulheres diferentes?", hesita e conta nos dedos: "Anacleta, três filhos. Fatita, dois filhos. Leopoldina, dois filhos...". Todos os filhos possuem nomes de bebidas: "Quando a minha primeira filha nasceu, eu estava sentado num bar com uns amigos a beber uma Cuca. Ficou Cuca." (Idem: 60-61). Tal é exatamente o que ocorre com Faustino Manso: sete mulheres, com os mesmos nomes: Anacleta, Fatita, Leopoldina... E 18 filhos, todos com nomes de bebidas - inclusive uma "Cuca" e a própria "Laurentina", ambas marcas de cerveja, uma em Angola, outra em Moçambique.

Assim, o candongueiro "fictício" recebe apelido criado a partir do "real"; e Faustino 
Manso herda traços atribuídos a esse mesmo homem.

2) 0 terceiro andamento do romance começa com um capítulo-diário localizado em “Chez Rangel, Maputo". Ele tem como subtítulo "Fragmentos de uma entrevista a Ricardo Rangel”. O Chez Rangel é um bar pertencente a Ricardo Rangel, que ostenta os títulos de "Pai da Fotografia Moçambicana", por ter-se tornado influente fotojornalista, e "HomemJazz de Moçambique", devido a uma cobiçada coleção de discos. Rangel é uma figura histórica, conforme demonstra o documentário média-metragem Ferro em brasa (2008), dirigido por Licínio de Azevedo, cineasta brasileiro há muitos anos radicado em Moçambique. 4

O capítulo seguinte é narrado por Bartolomeu, que vai com uma cantora - a qual conhecera na casa do escritor Mia Couto - ao Chez Rangel. Ali, conhece "um pianista, sem mãos, que me assegurou ter sido um dos melhores amigos de Faustino Manso" (Idem: 173). Quando Bartolomeu se apresenta a ele como neto de Faustino, o pianista Marechal Carmona se entusiasma:

- Vê estas minhas mãos?

Eu não as via.

- São as mãos do Faustino Manso! - disse isto e calou-se, deixando-me intrigadíssimo. (idem: 175)

Por conta disso, Bartolomeu convence Laurentina a entrevistá-lo para o documentário. Ele perdera as mãos na guerra (aparentemente a da independência moçambicana, em 1964-74). Era faxineiro e ficou fascinado com um piano. Desenhou as teclas no chão e tentava tocá-las, com os pés, quando Faustino Manso o viu: "Ele ficou atrás de mim, um tempo largo, a ouvir-me tocar." (Idem: 184), e passou a dar-lhe lições do instrumento.

Entre o primeiro encontro e a entrevista com Carmona, um capítulo-diário mostra o encontro do narrador com o cantor João Domingos. Ele conta que "sofreu um acidente grave, em criança, ao brincar com um foguete, e deixou de ver durante 15 dias. Depois recuperou, e nunca mais teve problemas". Anos depois, ao consultar uma oftalmologista, ouviu dela: “Tecnicamente o senhor é cego. Não há nada que eu possa fazer para o ajudar. 
Custa-me a crer que consiga ver alguma coisa. Se realmente vê é com os olhos da alma. Desses não sei tratar". Ao procurar uma segunda opinião, outro médico fala que "é o primeiro cego que conheço a queixar-se de vista cansada..." (Idem: 181-182) ${ }^{5}$

Primeiro, o personagem Bartolomeu se dirige ao mesmo cenário por onde o autor passara antes. Em seguida, o "pianista sem mãos" parece ser a recriação literária do cego que enxerga. 0 conjunto João Domingos, bastante famoso em Moçambique, é citado posteriormente no romance como trilha sonora na casa de uma personagem.

O diário é um gênero textual no qual o autor em geral descreve experiências e sentimentos supostamente reais, ligado ao "espaço biográfico" conceituado por Arfuch (2010); não é, em princípio, identificado pela invenção. Evidentemente, um diário incluído no corpo de um romance não deve ser tomado de modo literal. Mas neste caso, como todos os capítulos-diário apresentam personagens, localidades e até bibliografia e filmografia verificáveis no mundo do real, e correspondência no enredo ficcional, o projeto de Agualusa nesta obra pode ser descrito como: mostrar como a experiência do real inspira a ficção, e como esta refigura os elementos para dar uma solução literária, de acordo com os propósitos do autor. Em outras palavras, o elemento biográfico é complementado com o elemento imaginário. Por isso os capítulos-diário de As Mulheres do Meu Pai configuram-se como um making-of do próprio romance: o leitor tem acesso a o que teria motivado o escritor a criar tais episódios e como se deu o processo de transformação dessa experiência em material ficcional.

É interessante destacar que, no capítulo "O pianista sem mãos”, citado acima, Bartolomeu narra que conheceu a cantora Georgina na casa de Mia Couto, o mais famoso dos escritores moçambicanos; também se diz que Faustino Manso havia trabalhado com Hugh Masekela e Ibrahim Abdullah, importantes músicos sul-africanos; em outra ocasião, insinua-se uma amizade entre Bartolomeu Falcato e o fotógrafo Jordi Burch (Agualusa 2012: 285), de maneira que os elementos do mundo do real também interferem no 
universo ficcional. Assim se confirma a interação problemática, não hierárquica e multifacetada entre realidade, ficção e mentira como um dos temas centrais da obra.

\section{Documentário como tema: quem está falando?}

Laurentina quer partir para a África com o objetivo de conhecer sua família biológica. Seu namorado, Mandume, sugere que façam um documentário sobre esse encontro. Eles recebem a notícia da morte de Faustino Manso ao comprar, no aeroporto, um jornal, no qual os obituários anunciam a pluralidade de famílias que ele teve.

No funeral, ao identificar-se como filha do falecido, é acolhida pela viúva de Manso, dona Anacleta, e convidada para uma espécie de recepção. Ali conhece Bartolomeu, neto do músico. Ele lhe propõe que façam outro documentário:

Gostaria de filmar contigo um documentário sobre a vida do velho Faustino. Um road movie. A minha ideia seria partir de Luanda, com um bom jipe, e parar em todas as cidades onde ele viveu: Benguela, Mossâmedes, Cape Town, Maputo, Quelimane e Ilha de Moçambique. Entrevistaríamos as pessoas que o conheceram, músicos que trabalharam com ele. (Idem: 37$)$

Entretanto, ao longo da narração, pouco se fala desse documentário, exceto na forma de depoimentos "colados" ao texto: de Dário Reis, que criou Laurentina em Lisboa; de Serafim Kussel, que conta a interessantíssima viagem do contrabaixo de Faustino; de Marechal Carmona, o pianista sem mãos; e, finalmente, Arquimedes Moran, amigo que ajuda a esclarecer fragmentos da biografia de Faustino.

A viagem leva Laurentina a conhecer quase todas as mulheres de Faustino Manso: 1) em Luanda, dona Anacleta, a oficial; 2) no sul de Angola, Fatita de Matos, a "amante infeliz"; 3) em Namibe, Leopoldina já havia morrido, e Laurentina conversa com os filhos dela, Victoria e Babaera; 4) em Cape Town, Seretha du Toit, com quem Faustino não teve filhos; 5) em Maputo, Elisa Mucavele, que se separou do músico após uma série de traições; 6) em Quelimane, Ana de Lacerda, a curandeira; 7) na ilha de Moçambique, Alima, mãe biológica de Laurentina.

Nenhuma dessas mulheres aparece no romance na forma de "depoimento", como no caso dos homens, mas sempre em conversas e entrevistas com Laurentina. Isso faz com que 
a elas não seja concedida voz na mesma medida que a eles, pois os capítulos são sempre narrados por outra personagem - em geral Laurentina. Isso pode ser devido ao fato de que eles falam sobretudo da vida profissional de Faustino Manso, de sua relação com a música (com exceção do primeiro, Dário Reis), enquanto elas narram a trajetória pessoal dele. Assim, são vistas em interação com a documentarista e suposta filha do "Seripipi Viajante", apelido do cantor e contrabaixista. Esse fato traz a questão de quem seria a "voz" do documentário de Laurentina.

Bill Nichols procura teorizar o documentário a partir de uma fórmula " $E u$ falo deles para você." A variação nos pronomes usados na frase estabelecerá diferenças de envolvimento do cineasta com o tema e também da postura esperada por parte do espectador. Por exemplo, os documentários contemporâneos realizados em primeira pessoa diriam “Eu falo - ou nós falamos - de nós para vocês.” (Nichols 2005: 40ss., itálicos do autor).

O documentário é, segundo Fernão Pessoa Ramos (2008), uma obra fílmica que faz asserções sobre o mundo; sua "voz" é conceituada por Nichols como o "meio pelo qual esse ponto de vista ou essa perspectiva singular se dá a conhecer. A voz pode defender uma causa, apresentar um argumento, bem como transmitir um ponto de vista." (Nichols 2005: 73).

Poderia o filme possuir mais de uma voz? Quem está falando no documentário?

Por um lado, o diretor ou a diretora é responsável pela escolha do tema, pela seleção dos personagens e depoimentos, pelo direcionamento das entrevistas, pelas condições de captação das imagens - tipos de lentes e filtros, forma de enquadramento, ângulos, cenários, distância -, ou, no caso de imagens de arquivo, pela escolha de quais serão utilizadas; pela determinação de que planos comporão o filme, com que duração e em que ordem; pela utilização de músicas ou outros recursos na trilha sonora; enfim, diversos fatores determinantes para a forma como a obra será fruída e que ficam invisíveis ao 
espectador. Nesse sentido, o diretor não pode deixar de ser visto como agente da enunciação.

Por outro lado, o emprego de entrevistas e depoimentos faz com que cada participante do filme faça uso da sua palavra, da sua versão, e seja responsável por aquilo que diz. 0 que o espectador vê explicitamente diante de si não são as decisões do realizador, e sim o entrevistado: seu rosto, suas expressões faciais e corporais, suas palavras. Cada participante do documentário deixa impressa no filme a sua voz, seu ponto de vista, sua história. Esse tipo de documentário não será também, por natureza, polifônico?

Essa reflexão, útil para qualquer documentário, se torna essencial para analisar $A s$ Mulheres do Meu Pai em função da estrutura especular e polifônica do romance. Analogamente, a "mão" que conduz o romance é a do autor Agualusa. Mesmo quando lhes dá a voz, na forma da narração em primeira pessoa, é a pena dele que escolhe as palavras. Entretanto, nesta obra específica a voz do autor deliberadamente se mistura e se confunde com as dos personagens fictícios. Não há hierarquia entre voz do narrador e dos personagens, porque em As Mulheres do Meu Pai não há hierarquia entre realidade e ficção. Enfim, o autor cria e "dirige" as personagens em suas andanças, organiza a narrativa, mas dá VOZ aos protagonistas dessa jornada - os capítulos são narrados por Laurentina, Mandume, Bartolomeu e pelo motorista "Pouca Sorte", bem com como em cartas e depoimentos de outros personagens. A existência dos capítulos-diário explicita esse movimento, que caracterizamos anteriormente como making-of: o autor se posiciona dentro da esfera diegética para mostrar como a narrativa é tecida, a partir de que elementos e critérios.

Os documentários clássicos eram estruturados em função de uma voz-over, isto é, de um narrador que não aparecia na tela e transmitia informações ao espectador. Não havia espaço para contestar o conteúdo narrado - Bill Nichols (Idem: 78) refere-se a esse recurso como "voz de autoridade" ou "voz de Deus". Essa estética ainda predomina nos documentários televisivos - que Fernão Pessoa Ramos (2008: 24) chama de 
"documentários cabo" - em canais especializados como History Channel ou National Geographic. Neles, cujos temas costumam ser a vida selvagem, biografias de pessoas célebres, fatos históricos e científicos, a imagem funciona como elemento de complemento e comprovação do que é enunciado pelos discursos de autoridade emitidos pela voz-over e pelas entrevistas e depoimentos.

O cinema documentário contemporâneo, por sua vez, é marcado por uma pluralidade de vozes, e o confronto de "verdades" e "versões" faz parte da estratégia discursiva dos filmes. Aqui, as entrevistas e depoimentos assumem papel decisivo, na medida em que cada participante é responsável pelo que diz.

No romance de Agualusa, os personagens são fictícios; possuem, portanto, uma autonomia mais limitada. Mas não teriam um estatuto semelhante ao dos participantes (atores) de documentários, que, ao se apresentarem para a câmera e estarem sujeitos à ação do diretor - que filmou de certa maneira, selecionará trechos de suas falas etc. -, passam de pessoas a personagens? Pois nenhum filme consegue dar conta da complexidade, da personalidade, da identidade de um indivíduo.

A busca de Laurentina pela vida de Faustino Manso levará a essa conclusão. Pois, após viajar por três países, conhecer e entrevistar tantas mulheres e parceiros dele, chega à remota Ilha de Moçambique e tem um encontro repleto de coincidências com um médico, Amândio Pinto de Sousa. Este lhe diz que Faustino fora um de seus melhores amigos, que tratara dele quando tivera "um problema muito desagradável": descobrira "que ele era estéril. (...) Foi sempre estéril. (...) Dezoito filhos e nenhum deles biológico. Faustino ficou arrasado quando eu lhe disse. Um trapo. Podes imaginar. A vida inteira posta em causo." (Agualusa 2012: 234).

É interessante observar como a dimensão ética do documentário é abordada. Na volta do grupo a Luanda, Mandume informa ao leitor que ele e Laurentina combinaram de não contar a Bartolomeu sobre a esterilidade do músico ("tal revelação afetaria muita gente - inclusive o próprio Bartolomeu - e teme a reação da família"), e que ela havia se recusado a entrevistar sua mãe biológica, Alima, para o filme. Isso "irritou ainda mais Bartolomeu. Ele acha que sem o testemunho dela o filme ficará mutilado." (Idem: 250) Ele provavelmente 
tem razão. Por outro lado, o documentário tornou-se secundário, e a diretora, para proteger a família, escolhe não incluir nele a descoberta que fizera. Vale a pena registrar a posição do documentarista brasileiro João Moreira Salles a esse respeito:

O que nós documentaristas temos de lembrar o tempo todo é que a pessoa filmada possui uma vida independente do filme. É isso que faz com que nossa questão central seja de natureza ética. [...] E a responsabilidade ética nos afasta da ficção (responsabilidade ética em relação ao personagem, bem entendido). (Salles 2015: 279, itálico no original)

Concretiza-se, para Laurentina, o que já havia sido anunciado em capítulo-diário no Primeiro Andamento. Porém, aquela observação inicial sobre a esterilidade tende a passar desapercebida numa primeira leitura, pois ali os personagens ainda são grandemente desconhecidos pelo leitor. Nesse ponto, fica nítido que quanto mais Laurentina parece estar se aproximando da verdade sobre Faustino Manso, mais descobre que são mentiras (ou ficções).

Tanto as mentiras quanto as ficções estiveram sempre presentes como temas essenciais do romance, desde a pergunta inicial com que o narrador do capítulo-diário sonha e que logo depois é enunciada por Dário Reis ("De quantas verdades se faz uma mentira?").

Essa pergunta inicial enseja a "mentira primordial" do romance, pois é este o título do primeiro capítulo narrado por Laurentina: "Mentiras primordiais". É quando sua mãe adotiva, Doroteia, morre, e Dário lhe entrega a carta contando da adoção. 0 adjetivo "primordiais" insinua que, no decorrer das páginas, o leitor se deparará com outras mentiras, e assim ocorre.

A imagem do sonho, com que o romance começa, é recorrente. No sétimo capítulo, "os sonhos cheiram melhor que a realidade" (Agualusa 2012: 29). No Terceiro Andamento, Laurentina narra: "Aline, a minha melhor amiga, sonha muito bem. Sonhar bem é talento raro, pouco reconhecido, pelo menos nos países europeus. Aqui em Moçambique, as 
pessoas que sabem sonhar costumam ser bastante respeitadas." Ela recebera um e-mail de Aline sobre um sonho, no qual "há um rapaz, de pé, tocando uma espécie de flauta, curva e aguda como um sabre". Ao terminar de ler, Laurentina olha para cima e vê "uma serigrafia de Chichorro: um rapaz, de pé, tocando uma flauta, etc." (Idem: 227-228).

No capítulo seguinte, Pouca Sorte rejeita dormir em hotéis, preferindo sua "carrinha" como quarto:

Incomoda-me ainda mais a possibilidade de efeatortivamente cair no sono, e sonhar os restos dos sonhos que alguém deixou para trás. Os colchões das camas de hotéis, sobretudo de hotéis baratos, acumulam no geral resíduos de sonhos rápidos, mal sonhados, não sendo de excluir a possibilidade de se contraia um ou outro pesadelo tresmalhado. Conhecem promiscuidade maior do que sonhar um sonho em segunda mão? (idem: 228-229)

Mais adiante, quando os personagens já estão de volta a Angola, o universo onírico retorna no título do capítulo "0 que distingue a vida dos sonhos" (Idem: 262). Mas nenhuma dessas menções é tão decisiva para o enredo quanto a cena na qual Laurentina sai no meio da madrugada de seu quarto no hotel em Cape Town e vai até o quarto de Bartolomeu, descrita como "um estupro, ou quase". O episódio é narrado por Bartolomeu com palavras vagas, e ele próprio mal sabe, na manhã seguinte, se foi real ou sonhado:

A única prova de que ela esteve aqui é o ardor distraído de um perfume um pouco doce, na minha pele, nos lençóis e almofadas. 0 eco de uma frase, 'As tuas mãos foram feitas para a taça dos meus seios', a memória indefinida de uns lábios acesos e de um corpo leve pousado sobre o meu. (...) Talvez, afinal, tenha sido um sonho. Um perfume - algo impossível de capturar - não constitui prova material. Menos ainda a memória de uma voz a soprar-me ao ouvido, 'As tuas mãos foram feitas para a taça dos meus seios', uma silhueta frágil contra a exígua claridade da janela. (Idem: 149)

Pouco à frente, Bartolomeu acrescenta outro elemento de dúvida a seu relato: “Antes de dormir estive a fumar a erva que o Brand me deu. (...) Talvez fosse a liamba. Muito boa, caramba!, dizem que é do sol do deserto." (Idem: 150). A "prova concreta” desse encontro só virá muito depois, quando Laurentina se descobre grávida. Até lá, pode ser efeito da 
maconha (liamba), sonho ou realidade. Dentro da ficção.

A autenticidade é tema de outro trecho narrado por Bartolomeu Falcato. É a história de quando ele conhecera Elisa Mucavele, uma das mulheres de Faustino Manso, anos antes, em um encontro de escritores em Barcelona. Elisa abrira o debate "com uma canção destinada, explicou, a convocar os bons espíritos e afastar os maus. A voz, ora num gemido, num zumbido, ora num vago alarido, desdobrando no ar lentas vogais misteriosas, deixou os espanhóis transidos de espanto." Quando o angolano lhe pergunta, em reservado, se ela teria "iniciação como curandeira", ela ri: "É apenas uma canção que a minha mãe me ensinou. Uma canção para adormecer meninos. Não tem nada a ver com espíritos. Mas os brancos adoram o número. É o número que eles esperam de uma escritora africana." Uma senhora faz a Elisa um elogio que ao leitor soa irônico: "Obrigada por ser autêntica - disselhe, lágrima nos olhos. - Nós, na Europa, matámos Deus e agora estamos órfãos. Perdemos a ligação com o sagrado." (idem: 178-179).

A mesma Elisa, ao receber em Maputo o telefonema de Bartolomeu pedindo entrevista sobre Faustino Manso, lhe diz: "Tu és neto do Faustino?! Incrível! Então és sobrinho dos meus filhos. Custa-me a acreditar. A vida cria enredos de que a ficção não é capaz." (idem: 180).

Ainda assim, a ficção e a literatura são menos tematizadas que o sonho e a imaginação, sempre relacionada a alguma "coincidência", conforme o exemplo acima. Dário Reis, em seu depoimento, menciona "uma daquelas coincidências que um escritor renegaria, por receio que a sua ficção perdesse verossimilhança, tirando o caso do Paul Auster, o qual, como sabes, aprecia as coincidências" (idem: 52). E o próprio narrador-autor anota a seguinte observação sobre um capítulo-diário: "(Ainda a propósito de misteriosas coincidências, que é onde a vida triunfa sobre a literatura.)" (idem: 126).

Em geral, o leitor sabe que, em uma obra de ficção, personagens e eventos do enredo são criados e articulados de modo a provocar certo efeito, não podendo ser considerados coincidência. No entanto, segundo o personagem Dário Reis, um excesso de coincidências tornaria a ficção menos verossímil, como se o autor as estivesse forçando. Talvez por isso o 
narrador do diário afirme que as coincidências tornariam a vida superior à ficção, pois se tem certeza de que não foram fabricadas, inventadas.

Por fim, no Quarto (e último) Andamento, os capítulos-diário são permeados pela presença de uma personagem surpreendente, a Bailarina. Sua primeira aparição é no apartamento do ator angolano Orlando Sérgio, em uma festa repleta de pessoas que, na ficção, parecem inverossímeis. A Bailarina é "uma rapariga alta, magra, de pele brilhante, muito negra, expressão enigmática, como a de uma máscara quioca". O narrador-autor pergunta se ela é amiga do dono da casa: “Não, não! Sou a Bailarina.", é a resposta. Mais tarde, Orlando lhe conta que ela já vivia com um sapador (soldado especializado em minas terrestres) no apartamento quando ele o comprou. 0 sapador foi trabalhar e morreu na explosão de uma mina. "No dia seguinte encontraram-na a dançar, nua, no campo de minas." (idem: 245-246).

- E o que [a Bailarina] faz aqui?

- Senta-se e respira. Não faz mais nada. Volta e meia bate à porta e deixo-a entrar. É uma espécie de fantasma, sem a impertinência dos fantasmas.

Encontrei-a de novo esta manhã, na praia, com os pés mergulhados na renda do mar. As mãos desenhando flores. Fiquei com a impressão de que só eu a via. (ibidem)

Convém recordar que esses capítulos-diário são insinuados, na estrutura da obra, como pertencentes ao "mundo histórico", ao mundo do real. Não é o único exemplo de que Agualusa parece selecionar da realidade, da experiência, os seus aspectos inverossímeis para deles construir a sua ficção. Ou pelo menos sugerir que esses elementos vieram da realidade. Seguindo a estratégia de espelhamento da obra, a Bailarina aparece no capítulo seguinte, num flashback narrado por Bartolomeu. Ali ela adquire poderes de vidência, pois acerta as previsões que faz para ele na borra de café:

Você está prestes a envolver-se com uma mulher casada. Este outro aqui, que parece a cabeça de um cavalo, este indica que fará em breve uma viagem importante, e que essa viagem mudará a sua vida. Também vejo que vai perder alguém que ama. 
Na semana seguinte morreu o meu avô e conheci Laurentina. Poucos dias depois partíamos em viagem. (idem: 249)

Entretanto, nos capítulos-diário essa habilidade não aparece. 0 narrador, da janela de seu apartamento, apenas a vê a dançar em uma lagoa muito poluída. "Os braços erguidos, ondulando; as mãos: borboletas adejando as asas. Os pés flutuando sobre o denso mistério. Reconheci-a pela postura, pela doçura dos gestos, e não, é claro, pelos traços do rosto, que dali não conseguia distinguir: a Bailarina!” A sensação sobrenatural se acentua quando o narrador repete a impressão de que assistia "a um espetáculo que parecia haver sido preparado só para mim." (idem: 294).

Entre a festa na casa de Orlando Sérgio e essa visão na lagoa há um hiato de quase um ano. As entradas no diário datam de 11 de março de 2006 e 16 de fevereiro de 2007, respectivamente.

O último capítulo do romance é datado de 16 de março de 2007, ou seja, exatamente um mês após o anterior. 0 narrador está em um hotel em Lobito, sul de Angola - próximo a Benguela, cidade incluída no "Roteiro de Faustino Manso". Ele resolve tomar um banho de mar: "Despi-me e entrei no mar - a água era lisa e tépida - com a sensação de que mergulhava na própria noite" (idem: 348). Então ocorre um fenômeno curioso: a água em torno dele se ilumina.

\footnotetext{
Movia os braços e cada movimento parecia gerar um tumulto de estrelas e girar ao meu redor. Conheço pessoas que passaram por essa experiência e entraram em pânico. Outras, em êxtase. Muitos falam em embriaguez, a maioria em sonho. 0 fenómeno é provocado por um pequeno organismo unicelular, a noctiluca, capaz de emitir luminescência, e chama-se ardência marítima ou, no sul de Portugal, agualusa. (ibidem)
}

Novamente a relação entre realidade e estado alterado de (in)consciência - pânico, embriaguez, sonho - é estabelecida. Mas, desta vez, é apresentada explicação científica ("verídica"). A presença do autor na narrativa, observável em todos os capítulos-diário, atinge o ponto máximo da citação de seu próprio nome, agualusa: por que outra razão ele 
citaria o nome pelo qual o fenômeno é conhecido no sul de Portugal, se ele próprio é angolano e o episódio se passa em Angola?

Ao sair da água, ele vê a Bailarina estendida na areia e senta-se ao lado dela. É ela quem pronuncia a frase final do romance: “- Leve os sonhos a sério - sussurrou. - Nada é tão verdadeiro que não mereça ser inventado." (Ibidem)

\section{Considerações finais}

As Mulheres do Meu Pai, de José Eduardo Agualusa, incorpora influências e elementos da estética cinematográfica em pelo menos três aspectos.

Em primeiro lugar, a ideia para o romance começa como plano de "um roteiro para um filme musical, ou com um forte componente musical, sobre a situação das mulheres no cone sul de África” (Agualusa 2012: 25). A obra resultante não é cinematográfica, mas apropria-se de elementos desta arte. 0 componente musical é atenuado, surgindo na profissão do personagem biografado. E seu tema principal não é a "situação das mulheres", mas a busca de uma mulher portuguesa pela "verdade" de sua genealogia na África.

O segundo aspecto é a atividade documentária da protagonista. A narrativa consiste na pesquisa e realização de um documentário por Laurentina, Mandume e Bartolomeu. Deste modo, entrevistas e depoimentos, recursos típicos desse gênero fílmico, são intercalados às suas experiências. Embora a narração por vezes deixe de lado esse filme, ele é a razão para que a viagem aconteça, e tem consequências vitais para a conclusão do romance, quando a revelação da esterilidade de Faustino Manso coloca os produtores em situações antagônicas.

Por fim, o cinema documentário está presente na própria estrutura do romance, na medida em que os capítulos-diário apresentam as condições de escritura do próprio romance, expondo suas premissas, suas condições de planejamento e realização e algumas de suas inspirações e limitações, à semelhança dos making-of; neste caso, um making-of de si mesmo.

José Eduardo Agualusa e Karen Boswall não realizaram seu filme musical sobre as mulheres africanas, mas o primeiro fez do romance resultante dessa parceria uma obra 
profundamente marcada pela influência do cinema e, especificamente, do cinema documentário.

\section{Notas}

${ }^{1}$ Documentário dirigido por Karen Boswall, 2001.

20 romance foi editado em 2007 simultaneamente Edições Dom Quixote (Portugal) e Língua Geral (Brasil). Neste trabalho utiliza-se como referência a edição brasileira de 2012.

3 Os dois filmes dirigidos por Karen Boswall mencionados no romance, Dancing in the Edge (2001) e Marrabentando (ou Marrabenta Stories) podem ser acessados no perfil da cineasta na plataforma Vímeo ou por meio de seu website oficial: respectivamente, https://vimeo.com/43732744 e http://www.karenboswall.com/the-stories-my-guitar-sings.

${ }^{4}$ Ferro em Brasa está disponível na plataforma YouTube: https://www.youtube.com/watch?v=JXnQ0aNlXE4.

5 Por ocasião do falecimento de João Domingos, em 2016, o tabloide moçambicano Verdade republicou em seu website um texto no qual o cantor narra (entre outras histórias extraordinárias, que certamente não estariam deslocadas na prosa de Agualusa) como ficou cego: "falando com toda a franqueza - clinicamente - eu sou cego. Se eu for convosco à oftalmologia para fazer os testes pode-se concluir que sou invisual, não obstante estar a ver." Disponível em http://www.verdade.co.mz/tema-de-fundo/35/59408. 


\section{Bibliografia}

Agualusa, José Eduardo (2012), As Mulheres do Meu Pai, Rio de Janeiro, Língua Geral.

Arfuch, Leonor (2010). O Espaço Biográfico. Dilemas da subjetividade contemporânea, tradução de Paloma Vidal, Rio de Janeiro: Ed.Uerj.

Aumont, Jacques / Michel Marie (2003). Dicionário Teórico e Crítico de Cinema, tradução de Eloisa Araújo Ribeiro, Campinas, Papirus.

Nichols, Bill (2005). Introdução ao Documentário, tradução de Mônica Saddy Martins, Campinas, Papirus.

Ramos, Fernão Pessoa (2008). Mas, Afinal... O Que É Mesmo um Documentário?, São Paulo, Editora SENAC.

Salles, João Moreira (2015), "A dificuldade do documentário", in A Verdade de Cada Um, São Paulo, CosacNaify, 266-281.

Verdade, "Faleceu João Domingos, um idoso que sabia tocar viola e conhecia a cura da Sida (1933-2016)", 12.set.2016, <http://www.verdade.co.mz/tema-de-fundo/35/59408> (último acesso em 27.jul.2019).

\section{Filmografia}

DANCING in the Edge. Direção: Karen Boswall. Produção de Karen Boswall. Helsinki: YLE TV2 Documentaries; Maputo: Catembe Produções, 2001. 46 min. Disponível em https://vimeo.com/43732744 (último acesso em 29.jul.2019).

MARRABENTA Stories ou Marrabentando: The Stories my guitar Sings. Direção: Karen Boswall. Produção de Francisco Villa-Lobos. Lisboa: Contracosta Produções; Maputo, 
Catembe Produções; Maputo, Íris Imaginações, 2004. Disponível em http://www.karenboswall.com/the-stories-my-guitar-sings. $65 \mathrm{~min}$. (último acesso em 29.jul.2019).

RICARDO Rangel: Ferro em Brasa. Direção: Licínio Azevedo (2009). Produção de Camilo de Sousa e Luis Correia. Maputo: Ébano Multimédia; Lisboa: LX Filmes, 2006. 52 min. Disponível em https://www.youtube.com/watch?v=[XnQ0aNlXE4 (último acesso em 29.jul.2019).

Daniel Moutinho Souza atua como docente de Português e Literaturas em Língua Portuguesa no Colégio Pedro II, no Rio de Janeiro. Mestre e Doutor em Literatura Comparada pela Universidade Federal do Rio de Janeiro (títulos defendidos em 2015 e 2019, respectivamente); graduado em Comunicação Social - Jornalismo (UFRJ, 2002), licenciado em Letras Português-Inglês (Universidade Estácio de Sá, 2007) e especialista em Estudos Literários pela Universidade do Estado do Rio de Janeiro (Uerj, 2008). Tem como área de interesse de pesquisa a relação entre a literatura e outras artes, bem como as narrativas metaficcionais. 